\title{
The A6S Information Literacy Model for Digital Age Library instruction
}

\author{
Arman ${ }^{* 1, a}$, Murni Winarsih, \& Nurdin Ibrahim \\ Department of Educational Technology, Postgraduate of State University of Jakarta, Jakarta, 13220, Indonesia \\ a armanamir_lpg@yahoo.co.id \\ ${ }^{*}$ Corresponding Author
}

How to Cite : Arman, A., Winarsih, M., Ibrahim, N. (2019). The A6S Information Literacy Model for Digital Age Library instruction. International Journal for Educational and Vocational Studies, 1 (8), 831-837. DOI: https://doi.org/10.29103/ijevs.v1i8.2269

\section{ARTICLE HISTORY}

Received: 10 September 2019

Revised: 22 October 2019

Accepted: 24 November 2019

\section{KEYWORDS}

Information Literacy; Instructional Design; Library Instruction;

\section{ABSTRACT}

Information literacy has became a central issue of modern society. The rapid growth of information technology (IL) and the emergence of new digital devices not only require changes in the concept of IL itself, but also in practice. This paper discusses findings of study of design and development research with the goal of study was to develop the development of blended model of information literacy instruction (ILI) for higher education library instruction. Data were collected through a checklist, pretest, posttest, and attitude questionnaire throughout a series of formative evaluation stages. The data obtained were analyzed qualitatively and quantitatively. The result showed that the A6S (analyze, select, search, sort, synthesize, share, and self-evaluation) information model effective to enhance students' IL. offered recommendation regarding implementation in library instructions.

This is an open access article under the CC-BY-SA license.

\section{INTRODUCTION}

The explosion of information has raised new entities, information society that is connected in real-time access, both through satellite transmission and fixed undersea cables. The faster and cheaper access to information provides opportunities for students to live more productive in the twenty-first century by becoming skilled consumers as well as producers of information in various sources and formats. In schools and colleges, internet resources provide abundant and up-to-date information for educators and students. Not surprisingly, nowadays the internet has become "the main source for students" in seeking academic information. The problem now is how to prepare students using the technology that they have at their fingertip, which enable them in evaluating and transforming information into their new knowledge ethically and legally.

The interaction of students with digital tools as part of their daily life causes them to feel competent and overconfident when faced with information-seeking tasks (Mahmood, 2016). On the other hand. Çoklar, Yemen, and Yurdakul found that their status as people born in the digital age (digital native) does not have a significant effect on their online searching strategies (Çoklar, Yaman, \& Yurdakul, 2017). Not surprisingly, students often had difficulty in evaluating and synthesizing online-information from various sources in order to evaluate reliability, accuracy, authority, currency, coverage, and point of view or bias (Parsazadeh, Ali, \& Saeed, 2015). In fact, every time they connect to the internet they will be faced with a massive flow of information without any filter.

Saunders refutes the assumption that information literacy education has been obtained by students at previous levels of education. She found that many students started their learning activities by trial and error (Saunders, 2013). In this context, preparing students with information literacy skills is crucial, as these skills literacy skills are the key of students' success in higher education. This is also an answer to complaints raised that college graduates did not have the skills and abilities needed in the workplace (Walsh, 2015). Kavšek, Peklaj, \& Žugelj recommended that it is very crucial for higher education institutions to deliver information literacy training which will enable students to use their newly acquired knowledge as soon as possible in finding relevant information and evaluating the quality and usefulness of information resources and using them to build new knowledge (Kavšek, Peklaj, \& Žugelj, 2016). 
The main objective of the paper is proposing a theoretical model of Information literacy instruction which accommodate changes in the concept of information affected by the rapid growth of information technology and the emergence of new digital devices literacy, There are very few institutions of higher education have the "perfect" model of information literacy nevertheless; several examples of direct and indirect information literacy programs exist (Travis, 2017).

\section{METHODS}

This study was a mixed method approach, the type of research in which a researcher or team of researchers combines elements of qualitative and quantitative research approaches(Creswell \& Clark, 2011). The types and number of participants, information criteria, and data collection techniques are presented in table 3

Table 3. Framework of formative evaluation data collection

\begin{tabular}{|c|c|c|c|c|}
\hline \multirow{2}{*}{ Data Collection Method } & \multicolumn{4}{|c|}{ Formative evaluation phases } \\
\hline & Expert review & Individual review & Small-Group Trial & Field Trial \\
\hline Participant & Experts & Students & Students & Students \\
\hline Number of participant & 4 & 3 & 9 & 30 \\
\hline Criteria & $\begin{array}{l}\text { Content, design, } \\
\text { technical quality }\end{array}$ & $\begin{array}{c}\text { Clarity, appeal, obvious } \\
\text { errors }\end{array}$ & $\begin{array}{c}\text { Effectiveness, } \\
\text { motivational aspect } \\
\text { (attention, relevance, } \\
\text { confidence, and } \\
\text { satisfaction, }\end{array}$ & $\begin{array}{l}\text { Effectiveness, motivational } \\
\text { aspect (attention, relevance, } \\
\text { confidence, and satisfaction, }\end{array}$ \\
\hline Data collection & checklist & checklist & $\begin{array}{c}\text { Pretest, posttest, } \\
\text { attitude questionnaire }\end{array}$ & $\begin{array}{c}\text { Pretest, posttest, attitude } \\
\text { questionnaire }\end{array}$ \\
\hline
\end{tabular}

Adapted from Tessmer (1993), and Roblyer (2015)

The effectiveness of the ILI model developed was examined through pre-test and post-test. The data was analyzed using sample t-tests. the effect size was calculated using the Cohen eta-squared formula.

\section{RESULTS AND DISCUSSION}

\section{Results}

The blended ILI model proposed The A6S (analyze, select, search, sort, synthesize, share, and self-evaluation) was developed to accommodate changes in the concept of information literacy with the basic assumption that learning should be designed to facilitate individual knowledge construction by helping learners engage in an authentic task and meaningful conversation around the task. It was carefully designed and developed through systematic instructional design stages, based on The ACRL IL standards for higher education, and grounded in contemporary theories of learning, instruction, and andragogy

The A6S is an iterative model consisting of six main components. These components describe the stages of blended learning with information. Each stage will complete the next one. At the end of each step, learners conduct a self-evaluation of the process carried out and the results obtained and do revisions if necessary. The components and sub-components of the A6S model are presented simply in Figure 1.

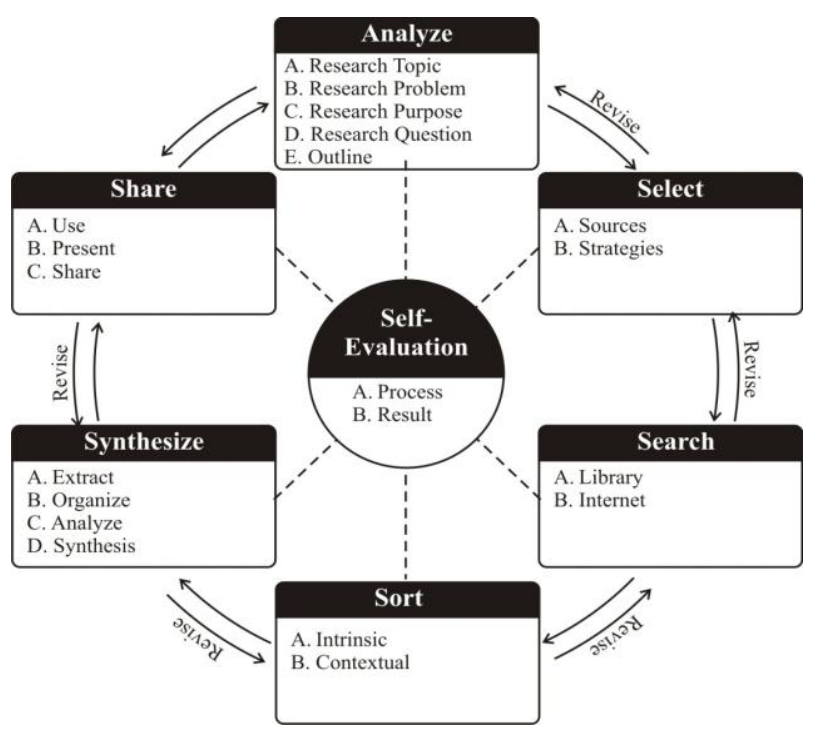

Figure 1. The A6S Model Components 
The first component, analysis, is the process that involves identifying and evaluating related to the purpose of information seeking. Students begin to investigate the problem and answer the objectives to be achieved during the research process. When faced with the task of searching information sources for research papers, presentations, or just information, it is very important to ensure that all requirements for assignments, types of assignments, and objectives are well understood and clear, both in terms of substance, rules of writing (length format, fonts and citations), collection deadlines, and method of assessment. Understanding requirements is key to the success or failure of an assignment because it relates to the components that will be assessed from an assignment.

At this component, develop a description of the topic and explore each relationship between topics, idea or another related concept.

The second component, select, is related to choosing and determining information sources and search strategies. Scientific writing in nature is a collection of information, ideas, facts, theories, and empirical data that fulfilling scientific rules and ethics and procedures. This collection of information is spread throughout all scientific papers, starting with the introduction, methods, results, and discussion (IMRAD). Therefore, it is very important for students to understand the role of information in writing scientific papers, differentiating sources of information to determine where the sources are, and determining the right tools and strategies to track information effectively and efficiently

At this stage the instructor must ensure students are able to choose the right sources of information (primary and secondary, physical and electronic), and choose effective strategies, both in the library (conventional or digital) and the internet (search engines, Meta Search Engines, Directory, Subject gateways, or Invisible web/ specialized database).

The third and fourth components, search and sort, are a combination of applying a predetermined search strategy and sorting information based on good information criteria. The search step is the application of the right tools and techniques to meet information needs. Meanwhile, sorting refers to evaluating information sources through an investigation process to decide the feasibility of information sources by evaluating the dimensions of information quality: intrinsic (accuracy, objectivity, trustworthiness, and reputation), contextual (relevance, added value, timeliness, completeness, and number of data), accessibility (access and security dimensions), representational (interpretation, consistency, conciseness, and ease of understanding).

At this stage the instructor must ensure that students are able to: first, apply the steps to search information in the library effectively: 1) determine the type and source of information needed, 2) identify the location of the source of information, 3) record the source of information identity, 4) find the location of the source of information, 5) evaluate the source of information, and 6) mark the source of information. Second, implementing information seeking steps on the internet effectively includes: 1) determining the right keywords and relevant information needs 2) conducting searches using the right tools: a) search with phrases, b) search with Boolean logic, c) search with filters, d) search with advanced operators, e) search with meta-search engines, and f) apply combination search, 3) evaluating sources of information, and 4) marking sources of information.

The fifth component, synthesis, deals with extracting, organizing, quoting, paraphrasing, summarizing, analyzing and synthesizing information to build new knowledge. The use of information legally and ethically is the ultimate goal of the stage. After deciding that the information obtained is good enough to use, the next task is to combine the information to answer the research question.

At this stage the instructor must ensure that students are able to: 1) extract information, related to reading, scanning, listening, classifying, copying, and storing information in a document to capture and produce factual information contained in it, 2) organize related information by arranging and grouping information systematically based on categories/concepts, chronological, hierarchical, or alphabetical, placing ideas/ideas by: a) quoting, which is duplicating the exact words as found in the original source, b) paraphrasing, i.e. restate the main idea or meaning of a source using words and sentence structures that are different from the original source, and c) summarize that is choosing the main idea from a source of information, writing it with words and sentence structures that are different from the original source by giving emphasis on the most important points, 3) analyze, describe or elaborate complex concepts into smaller parts that are more detailed and explain the interrelationships or relationships between these parts to get a better understanding, and 4) synthesis, related to building new knowledge from different ideas and pieces of information, and connecting they together become a coherent whole to get a new perspective.

The sixth component, share, refers to making decisions to use and present new knowledge that has been built to others in the format that is most appropriate for presenting information (for example, visual, oral, or multimedia) and then communicating it in an ethical and legal manner.

To be able to successfully present and communicate information effectively, ethically and legally the instructor must ensure students have the ability to manage content, articulate knowledge and skills from previous experience, integrate new and previous information, and manipulate digital text or images, and so on. They also need to be able to choose a media or other communication format that supports the product goals and intended audience, combines design and communication principles, and communicates clearly with 
the style that supports the needs of the intended audience.

The final component of the A6S model is Self-evaluation, refers to a reflection activity on the process and results of the student's investigation. Throughout the investigation process, students must routinely monitor their own investigation progress. Students must also be able to measure whether the quality of their assignments is in accordance with what they want and the process has been carried out properly and correctly, ethically and legally. To be able to use information ethically and legally, the instructor must ensure students understand issues related to privacy and security, free access and paid access, and limitations and freedom of speech. They must also show an understanding of intellectual property, copyright, and the use of copyrighted material properly. In addition, students must obtain, store and disseminate text, data, images or sounds legally and demonstrate their understanding of plagiarism.

The A6S ILI model is conducted in blended way which combine online learning and face-to-face instruction, where all course material can be accessed online. The online discussion are followed the face-to-face instruction through the follow through activities.

The effectiveness of the A6S ILI model was examined at the small group trial, the table 3 shows that the $p<0,05$ which it can be concluded that there was a statistically significant difference between pretest and posttest mean. The calculation of $\mathrm{t}$ value using Cohen eta squared formula showed that the ILI model developed had a strong effeft to students information literacy $(0,74>0,5$.

Table 3. Paired sample t-test tabel for small group trial

\begin{tabular}{|c|c|c|c|c|c|c|c|c|c|c|}
\hline \multicolumn{11}{|c|}{ Paired Samples Test } \\
\hline & & \multicolumn{5}{|c|}{ Paired Differences } & \multirow{3}{*}{$\mathrm{t}$} & \multirow{3}{*}{$d f$} & \multirow{3}{*}{ Sig } & \multirow{3}{*}{ (2-tailed) } \\
\hline & & \multirow[t]{2}{*}{ Mean } & \multirow[t]{2}{*}{ Std. Deviation } & \multirow{2}{*}{$\begin{array}{l}\text { Std. Error } \\
\text { Mean }\end{array}$} & \multicolumn{2}{|c|}{$\begin{array}{l}\text { 95\% Confidence Interval of the } \\
\text { Difference }\end{array}$} & & & & \\
\hline & & & & & Lower & Upper & & & & \\
\hline Pair 1 & Pretest - Postest & $-13,61111$ & 4,52616 & 1,50872 & $-17,09022$ & $-10,13200$ & $-9,022$ & 8 & &, 000 \\
\hline
\end{tabular}

In the field trial The effectiveness of the A6S ILI model can be seen in the table 4. Based on the SPSS analysis, it revealed the the $\mathrm{p}<0,05$ which it can be concluded that there was a statistically significant difference between pretest and posttest mean. The calculation of $t$ value using Cohen eta squared formula showed that the ILI model developed had a strong effeft to students information literacy $(0,95>0,5$.

Figure 2 shows that students' had good perception on the ILI model involve: attention level, relevance level, self-confidence level, and satisfaction level.

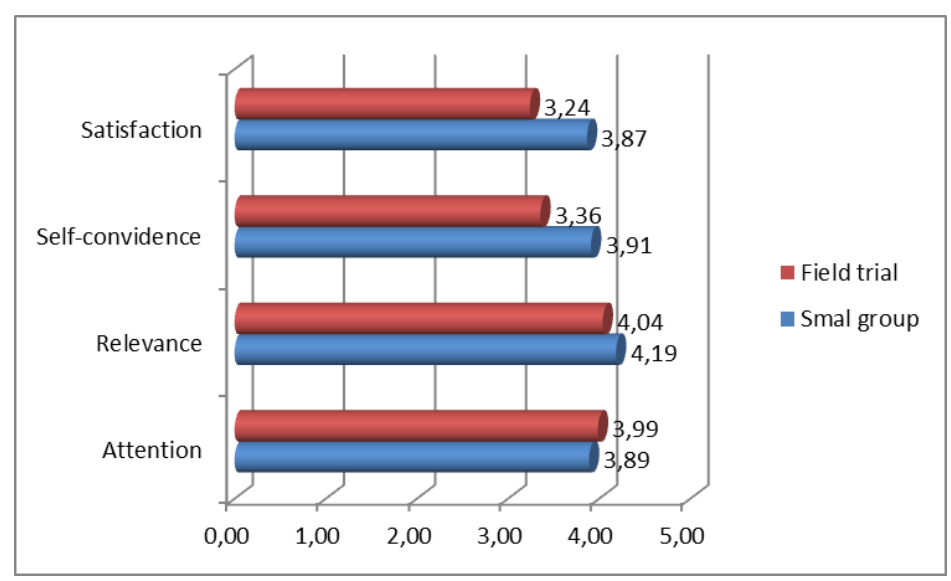

Figure 2. Students' perception on the The A6S ILI Model

Based on these findings, it can be conluded that The A6S ILI model were effective and had a good appeal in increasing students' information literacy.

\section{Discussion}

Researching and writing scientific works, both papers, reports, articles and so on through a process of inquiry and information retrieval is a form of assignment that is generally given to students of higher education. These assignments are intended to communicate knowledge, develop activities of creativity and understanding, solve problems, find answers, and build new knowledge. Inquiry-based learning models generally involve: making observations; posing questions; examining books and other sources ofinformation to see what is already known; planning investigations; reviewing what is already known in light of experimental evidence; using tools to gather, analyze, and interpret data; proposing answers, explanations, and predictions; and communicating the 
results (NRC, 2000). This explains, that the learning process in higher education is closely related to information literacy skills to solve problems and answer various questions. In other words, information literacy skills are the key to the successful implementation of inquiry-based learning models.

Grounded in contemporary theories of learning, instruction, and pedagogy, the A6S model was designed and developed carefully based on the stages of the ADDIE instructional design approach. At the end of the development stages, the model is implemented and evaluated through a series of formative evaluations, involves: expert judgment, one-on-one with students, small group evaluation, and field trials. The six stages of the A6S model not only offer a clear way of answering information needs in decision making to determine the right solution to solve problems related to information retrieval, but also increase opportunities for students to become independent learners, because they are involved in using various sources of information to expand their knowledge and sharpen critical thinking and reflection. The main strengths of the ADDIE approach lie in the self-refining component and its iterative nature, allowing learners to more quickly identify and correct errors early on, both faulty assumptions, negligence, and data. The A6S information literacy instruction theoretical model awaits to be validated on a larger scale.

The status of students as people born in the digital age (digital native) does not have a significant effect on students online information searching skills, so it is very important for higher education institutions to hold information literacy training to equip students with the ability to find relevant information and evaluate the quality and usefulness of resources information power.

\section{CONCLUSION}

IL are the key to successful learning in higher education, so planning and developing information literacy learning models must accommodate changes in the concept of information affected by the rapid growth of information technology and the emergence of new digital devices. The A6S ILI model emphasizes providing students with inquiry and problem solving skills in an information-rich environment. The six steps of the A6S inquiry model not only offer a clear way of answering information needs in decision making to determine the right solution to solve problems related to information retrieval, but also increase opportunities for students to become independent learners, because they are involved in using various sources of information to expand their knowledge and sharpen critical thinking. Iterative nature allows students to more quickly identify and correct errors early on, both errors in the process and results. Blended learning provides opportunities for ongoing social interaction between teachers and students and between students during face-to-face sessions and online sessions. These interactions are the basis for developing a sense of togetherness. Integrating blended learning into library instruction will promote the effectiveness of ILI in the information-rich environment. Future research can focus on how to plan and design an instructional model library that bridges instructional, information, learning, learning design theories, in an online or another types of blended instruction model so that freed class-time instruction is offered by face-to-face instruction.

\section{Acknowledgements}

Thanks to Dr. Murni Winarsih, M.Pd and Prof. Dr. Nurdin Ibrahim, M.Pd. for giving me your guidance, patience, and being being the best supervisors.

\section{REFERENCES}

ACRL. (2000). Information literacy competency standards for higher education. Chicago, IL: American Library Association.

Afacan, Y. (2018). Student experiences of blended learning in interior architecture. Journal of Information Technology Education: Research, 17, 399-422.

ALA, \& AECT. (1998). Information power: Building partnerships for learning. http://www.ala.org/ala/aasl/aaslproftools/informationp ower/InformationLiteracyStandards_final.pdf

Arends, R., \& Kilcher, A. (2010). Teaching For Student Learning. New York: Taylor \& Francis.

Barbazette, J. (2013). How to write terrific training materials: Methods, tools, and techniques. San Fransisco: John Wiley \& Sons.

Bawden, D. (2001). Information and digital literacies: a review of concepts. Journal of documentation, 57(2), 218-259.

Branch, R. M. (2009). Instructional design: The ADDIE approach (Vol. 722). New York: Springer Science \& Business Media.

Bundy, A. (2004). Australian and New Zealand Information Literacy Framework: Principles, Standards and Practice 2. http://wwwxaulxdu.au/InfoLiteracv/lnfoLiteracyFrame work.pdf

Çoklar, A. N., Yaman, N. D., \& Yurdakul, I. K. (2017). Information literacy and digital nativity as determinants of online information search strategies. Computers in human behavior, 70, 1-9.

Crawford, J. (2006). The use of electronic information services and information literacy: A Glasgow Caledonian University study. Journal of Librarianship and Information Science, 38(1), 33-44.

Creswell, J. W., \& Clark, V. L. P. (2011). Designing and conducting mixed methods research. California: Sage publications. 
Doran, R. L. (2002). Science educator's guide to laboratory assessment. Danvers, MA.: NSTA press.

Feng, L., \& Ha, J.-L. (2016). Effects of Teachers' Information Literacy on Lifelong Learning and School Effectiveness. Eurasia Journal of Mathematics, Science \& Technology Education, 12(6).

Gagne, R. M., Wager, W. W., Golas, K. C., Keller, J. M., \& Russell, J. D. (2005). Principles of instructional design. Belmont, CA: Wadsworth.

Gilster, P. (1997). Digital literacy. New York: Wiley Computer Pub. .

Goodman, V. D. (2009). Keeping the user in mind: Instructional design and the modern library. Cambridge: Elsevier.

Haythornthwaite, C., \& Andrews, R. (2011). E-learning theory and practice. London: Sage Publications.

Hepworth, M., \& Walton, G. (2009). Teaching information literacy for inquiry-based learning. Oxford: Chandos Publishing.

Horn, M. B., \& Staker, H. (2017). THE Blended WORKBOOK: Learning to Design the Schools of Our Future. San Fransisco: Wiley.

IFLA. (2011). IFLA media and information literacy recommendations [Press release]. Retrieved from https://www.ifla.org/files/assets/information-literacy/p ublications/media-info-lit-recommend-en.pdf

Innes, R. B. (2004). Reconstructing undergraduate education: Using learning science to design effective courses. New Jersey: Lawrence Erlbaum Associates.

Ju, S. Y. (2018). Perceptions and practices of blended learning in foreign language teaching at USIM. European Journal of Social Sciences Education and Research, 12(1), 170-176.

Kan'an, A. (2018). The Relationship between Jordanian Students' 21 st Century Skills (Cs21) and Academic Achievement in Science. Journal of Turkish Science Education (TUSED), 15(2).

Kavitha, R. K. J., W. ( 2019). A study on the student experiences in blended learning environments. International Journal of Recent Technology and Engineering, 7., 183-186.

Kavšek, T., Peklaj, C., \& Žugelj, U. (2016). Information literacy training evaluation: the case of first year psychology students. The Journal of Academic Librarianship, 42(4), 293-299.

Kguchi, A. (2015). Educational Robotics as a Learning Tool for Promoting Rich Environments for Active Learning (REALs). In J. Keengwe (Ed.), Handbook of Research on Educational Technology Integration and Active Learning (pp. 19-47). Hershey, PA.: IGI Global.

Khatun, M., Virkus, S., \& Rahman, A. J. (2015). Digital information literacy: a case study in Oslo public library. Paper presented at the European Conference on Information Literacy.
Lanham, R. A. (1995). Digital Literacy. Scientific American, 3(273), 198-199.

Lanning, S. (2017). Concise guide to information literacy. California: ABC-CLIO.

Lin, Y.-W., Tseng, C.-L., \& Chiang, P.-J. (2017). The Effect of Blended Learning in Mathematics Course. Eurasia Journal of Mathematics, Science \& Technology Education, 13(3).

Lombard, E. (2010). Pursuing information literacy: Roles and relationships. Cambridge: Chandos Publishing.

Mackey, T. P., \& Jacobson, T. E. (2014). Metaliteracy: Reinventing information literacy to empower learners. Chicago: American Library Association.

Mahmood, K. (2016). Do people overestimate their information literacy skills? A systematic review of empirical evidence on the Dunning-Kruger effect. Communications in Information Literacy, 10(2), 3.

Morrison, G. R., Ross, S. J., Kemp, J. E., \& Kalman, H. K. (2007). Designing effective instruction. New Jersey: Wiley.

NRC. (2000). Inquiry and the national science education standards: A guide for teaching and learning. Washinton, DC: National Academies Press.

O’Rourke, K., \& Kahn, P. (2005). Understanding enquiry-based learning. In T. Barrett, I. Mac Labhrainn \& H. Fallon (Eds.), Handbook of enquiry and problem-based learning; Irish case studies and international perspectives. Galway: AISHE and NUI Galway.

Ormrod, J. E., \& Davis, K. M. (2004). Human learning. London: Merrill

Osguthorpe, R. T., \& Graham, C. R. (2003). Blended Learning Environments Definitions and Directions. The Quarterly Review of Distance Education, 4(227-233).

Oweis, T. I. (2018). Effects of Using a Blended Learning Method on Students' Achievement and Motivation to Learn English in Jordan: A Pilot Case Study. Education Research International, 2018.

Parsazadeh, N., Ali, R., \& Saeed, I. I. R. (2015). Digital information evaluation skills among students in higher education. Jurnal Teknologi, 75(11).

Roblyer, M. D. (2015). An introduction to systematc instructional design for traditional, online, and blended environments: essential steps and strategies to plan instruction for traditional, online, and blended classrooms. New Jersey: Pearson.

Rosman, T., Mayer, A.-K., \& Krampen, G. (2016). A longitudinal study on information-seeking knowledge in psychology undergraduates: Exploring the role of information literacy instruction and working memory capacity. Computers \& Education, 96, 94-108.

Saunders, L. (2013). Culture and collaboration: Fostering integration of information literacy by speaking the language of faculty. Paper presented at the Association 
of College and Research Libraries National Conference.

SCONUL. (2011). The SCONUL seven pillars of information literacy: Core model for higher education. London: Society of College, National and University Libraries Working Group on Information Literacy.

Shao, X., \& Purpur, G. (2016). Effects of information literacy skills on student writing and course performance. The Journal of Academic Librarianship, 42(6), 670-678.

Slavin, R. E. (2006). Educational psychology: Theory and practice. Boston:: Pearson.

Sylvester, C. (2015). More questions than answers? A review of the effectiveness of inquiry based learning in higher education. The Journal of Commonwealth Law and Legal Education, 10(1), 21-29.

Tessmer, M. (1993). Planning and conducting formative evaluations. Oxon: Routledge.

Thorne, K. (2003). Blended learning: how to integrate online \& traditional learning. London: Kogan Page Publishers.

Travis, T. A. (2017). From the classroom to the boardroom: The impact of information literacy instruction on workplace research skills. Education Libraries, 34(2), 19-31.

Walsh, J. (2015). Information literacy instruction: Selecting an effective model. Cambridge: Chandos Publication.

Welsh, T., \& Wright, M. (2010). Information literacy in the digital age: An evidence-based approach. Cambridge: Chandos Publishing.

Woolf, B. P. (2009). Building Intelligent Interactive Tutors: Student-Centered frategies for Revolutionizing E-Learning. Burlington: Morgan Kaufmann. 